\title{
THE NeW ABOLITION
}




\title{
BOOKS BY GARY DORRIEN
}

\author{
Logic and Consciousness
}

The Democratic Socialist Vision

Reconstructing the Common Good

The Neoconservative Mind: Politics, Culture, and the War of Ideology

Soul in Society: The Making and Renewal of Social Christianity

The Word as True Myth: Interpreting Modern Theology

The Remaking of Evangelical Theology

The Barthian Revolt in Modern Theology

The Making of American Liberal Theology:

Imagining Progressive Religion, 1805-1900

The Making of American Liberal Theology:

Idealism, Realism, and Modernity, 1900-1950

Imperial Designs: Neoconservatism and the New Pax Americana

The Making of American Liberal Theology:

Crisis, Irony, and Postmodernity, 1950-2005

Social Ethics in the Making: Interpreting an American Tradition

Economy, Difference, Empire: Social Ethics for Social Justice

The Obama Question: A Progressive Perspective

Kantian Reason and Hegelian Spirit:

The Idealistic Logic of Modern Theology 


\section{THE NEW}

\section{ABOLITION}

W. E. B. Du Bois and the Black Social Gospel

Gary Dorrien

Yale

UNIVERSITY

PRESS

New Haven E London 
Published with assistance from the Louis Stern Memorial Fund

Copyright (C) 2015 by Yale University.

All rights reserved.

This book may not be reproduced, in whole or in part, including illustrations, in any form (beyond that copying permitted by Sections 107 and 108 of the U.S. Copyright Law and except by reviewers for the public press), without written permission from the publishers.

Yale University Press books may be purchased in quantity for educational, business, or promotional use. For information, please e-mail sales.press@yale.edu (U.S. office) or sales@yaleup.co.uk (U.K. office).

Set in PostScript Electra type by IDS Infotech, Ltd.

Printed in the United States of America.

Library of Congress Control Number: 2015933802

ISBN: $978-0-300-20560-2$

A catalogue record for this book is available from the British Library.

This paper meets the requirements of ANSI/NISO Z39.48-1992 (Permanence of Paper). 10987654321 
For Professor Romeo Phillips,

treasured friend and educator extraordinary 
This page intentionally left blank 